\title{
ASSESSING THE EFFICACY OF DISSOLVED FERRIC CHLORIDE CONDITIONER ON DEWATERABILITY OF SEWAGE SLUDGE
}

\author{
J. I. Obianyo* \\ DePt. of Civil EngineERing, Michael OKPARA Univ. of Agriculture UMUdike UMUAhia, ABia State, NiGERIA \\ E-mail address: jiobianyo@yahoo.com
}

\begin{abstract}
The aim of this study was to investigate the efficacy of dissolved ferric chloride conditioner on dewaterability of sewage sludge. A funnel- shaped drying bed of $420 \mathrm{~mm}$ surface diameter, 340mm vertical depth, 25mm diameter discharge pipe was used in this study, and containing $75 \mathrm{~mm}$ thick sand layer, grain size $0.20 \mathrm{~mm}-0.60 \mathrm{~mm}$ diameter. On this layer was placed $200 \mathrm{~mm}$ thick sewage sludge thoroughly mixed with ferric chloride solution, introduced into the drying bed and filtration allowed to take place. Discharge from the control experiment was further and faster with maximum discharge of $201 \mathrm{~m}^{3}$ at the $400^{\text {th }}$ minute. Repeating the experiment on the $2^{\text {nd }}, 3^{\text {rd }}$, $4^{\text {th }}, 5^{\text {th }}$ and $6^{\text {th }}$ days, maximum discharges of $78 \mathrm{~cm}^{3}, 41 \mathrm{~cm}^{3}, 40 \mathrm{~cm}^{3}, 39 \mathrm{~cm}^{3}$ and $39 \mathrm{~cm}^{3}$ were experienced at the $300^{\text {th }}$ minute for the $2^{\text {nd }}$ day, 200 2 , minute for the $3^{\text {rd }}$ and $4^{\text {th }}$ days and $180^{\text {th }}$ minute for the $5^{\text {th }}$ and $6^{\text {th }}$ days respectively. Efficacy retardation factors were $2.577,4.902,5.025,5.154,5.154$ for the $2^{\text {nd }}, 3^{\text {rd }}, 4^{\text {th }}, 5^{\text {th }}$ and $6^{\text {th }}$ days. Minimum and maximum instantaneous inhibition coefficients were found to be 0.52 and 0.78 which indicates high inhibition. The result of specific resistance to filtration ' $R$ ' show that it increased tremendously when the salt is stored in solution. Specific resistance to filtration are $4.372 \times 10^{6} \mathrm{~m} / \mathrm{kg}, 1.924 \times 10^{12} \mathrm{~m} / \mathrm{kg}, 1.490 \times 10^{12} \mathrm{~m} / \mathrm{kg}$, $3.556 \times 10^{12} \mathrm{~m} / \mathrm{kg}, 2.310 \times 10^{12} \mathrm{~m} / \mathrm{kg}$ and $1.765 \times 10^{12} \mathrm{~m} / \mathrm{kg}$ in the $1^{\text {st }}, 2^{\text {nd }}, 3^{\mathrm{rd}}, 4^{\text {th }}, 5^{\text {th }}$ and $6^{\text {th }}$ days respectively. There was no consistent increase in these values, but seem to be fluctuating. This anomalous behaviour is a limitation in the work of Ademiluyi and Arimieari, and because of that, their model is not so good in the prediction of specific resistance to filtration.
\end{abstract}

Keywords: Efficacy, Dissolved ferric chloride, Dewaterability, Sewage sludge

\section{INTRODUCTION}

The presence of trapped air in ferric chloride containers alter its characteristics even though the remnants are stored in the solid state tightly closed in their containers after use. The moisture contained in trapped air is still being absorbed by the ferric chloride salt, so that an alternative way is to preserve the substance in solution. When solution of ferric chloride is stored in tightly closed containers, the system will attain vapour pressure equilibrium between the surface of the solution and moisture content of the surrounding air, and hence cannot absorb moisture from the trapped air. This study is aimed at determining whether the stored ferric chloride solution still retains its efficacy in terms of sludge dewatering as a conditioner. Dewatering is a physical unit operation used to reduce the moisture content of sewage sludge so that it can be handled and/or processed as a semi-solid instead of liquid [1]. Dewatering process increases solid content of sludge between 20 to $35 \%$ [2]. The handling of sewage sludge is one of the most significant challenges in wastewater management. In many countries, sewage sludge is a serious problem due to its high treatment costs and the risks to environment and human health. Dewatering of sewage sludge is not only found in removal of excess moisture but to render the sludge odourless and nonputrescible [3]. Dewatering of sewage sludge prior to drying or disposal is an important step because the lower the water content of the sludge, the less costly it will be to transport, the less liable to degradation and odour production, and the easier it will be to dry. Typical approaches involve addition of conditioning chemicals to increase the 
dewatering rate and improve filtrate quality, and then processing the sludge in centrifuges, belt presses or other dewatering units [4]. The paper [5] reported that sludge disposal as a growing problem for all wastewater leads to increased sludge production. Papers [6] and [7] proposed a sludge filtration equation for dewatering of sludge at constant pressure. Carman's work was based on the concept of specific resistance to filtration and the time velocity plot of sludge filtration at constant pressure. He postulated that specific resistance is independent of suspended solids concentration and assumed that the total loss of filtration pressure arises from pressure drop across filter cake, pressure drop across initial resistance and loss incurred in recovering filtrate. In [8], it was experimentally established that the plot of filtrate volume $(v)$ versus time $(t)$ followed parabolic relation in line with theoretical predictions based on Carman's equations. In [9], it was stated that the dimensions of length are spatially discriminated into $\mathrm{Lx}, \mathrm{Ly}$ and $\mathrm{Lz}(\mathrm{x}, \mathrm{y}, \mathrm{z})$ being three mutually perpendicular axes in space), and as well as making distinction between inertial mass, $M_{\mu}$, and the amount of matter, $M_{i}$.

For turbulent raw waters the sludge properties can also be affected by the proportion of precipitated coagulant to naturally present particles; arguably because the natural suspended solids are larger, and so denser, sludge produced from turbid water dewater faster and further [10,11]. The rate of precipitation and coagulation of ferric salts has been related to the molar hydrolysis ratio $\left[\mathrm{OH}^{-}\right\rfloor_{\text {added }} /[\mathrm{Fe}]$ , and the equivalent for $A l[12,13]$. It has been reported that there exists a threshold value of $\left[\mathrm{OH}^{-}\right]_{\text {added }} /[\mathrm{Fe}]$ in the range of $2.7-2.8$, above which rapid polymerization occurs, yielding a poorly ordered precipitate [14].

Most of the literature comparing alum and iron sludges reports that the ferric sludges dewater further $[10,15]$ and faster [11] than alum sludges [16]. Natural fluctuations in raw water quality can cause large changes in the consistency of wastewater treatment plants (WTP) sludge produced [17] through changes in the size, morphology, and strength of the underlying aggregate or floc structure.

On a fundamental level, the sludge dewaterability is controlled by the chemical composition and physical configuration of the aggregates or flocs that make up the sludge. It is hypothesized that the coagulation conditions will determine these parameters and hence determine sludge dewaterability. Important variables in the coagulation process are the coagulant dose, coagulant $\mathrm{pH}$ and the raw water quality - for example, how much natural organic and inorganic material it carries. These variables will dictate the composition of the sludge, for example the proportion of natural organic matter (NOM) and the phase of the coagulant precipitate formed. However, there is disagreement in the literature over whether NOM is detrimental [18], has no significant effect [19] or is beneficial to sludge quality. It has been discovered that an effective way of managing sewage sludge is by the use of conditioners. For instance, the production of potable water is conventionally carried out by coagulation with a hydrolyzing metal salt such as aluminium sulfate ('alum') or ferric chloride ('ferric'). This process is effective in removing turbidity, or colour and microorganisms, but also results in a waste byproduct as the coagulants precipitate into particles that aggregate to form 'flocs' [20]. It has been shown that linear relationship exists between seepage and time in conditioned sludge [21], and is given by the expression;

$s g=a+b t$

Where $s g=$ instantaneous seepage due to conditioning of sludge;

$a$ and $b$ are the intercepts and slopes when instantaneous seepage were regressed on time $t$ at various doses of coagulant, ' $a$ ' and ' $b$ ' can be expressed as linear functions of coagulant doses $Q$ as shown below;

$a=\lambda_{1}+\lambda_{2} Q$

$b=\beta_{1}+\beta_{2} Q$

In which $\lambda_{1}$ and $\lambda_{2}$ are the intercepts and slopes when various intercepts were regressed on various doses of coagulant $Q$, while $\beta_{1}$ and $\beta_{2}$ are the intercepts and slopes when various slopes ' $b$ ' were regressed on various doses of coagulant $Q$ [21].

\section{MATERIALS AND METHOD}

Moisture content test on the sludge was determined in accordance with[22]. The sample was $32.60 \mathrm{~g}$ of sewage sludge which was oven-dried at $105^{\circ} \mathrm{C}$. The container was removed from the oven from time to time and reweighed until there was no change in weight after two successive weighing. After the 
moisture content test, 2964.84g of sewage sludge was placed in a bucket. Based on moisture content of $60.32 \%$, the weight of moisture was $1788.39 \mathrm{~g}$ and $1500 \mathrm{~g}$ of water was added to enhance flowability making a grand total weight of sludge to be $4000 \mathrm{~g}$, thereby increasing the moisture content of sludge to $82.21 \%$

\subsection{Experimental set up}

The drying bed was funnel-shaped with $420 \mathrm{~mm}$ surface diameter, $340 \mathrm{~mm}$ vertical depth fitted with a $25 \mathrm{~mm}$ drain pipe and a gauze to prevent the sand from flowing out from the opening at the base. The sand was $75 \mathrm{~mm}$ thick while the sewage sludge occupied a thickness of $200 \mathrm{~mm}$.

This experiment lasted for six days. The first day, $20 \mathrm{~g}$ raw sample of $\mathrm{FeCl}_{3}$ was thoroughly mixed with $4000 \mathrm{~g}$ sample of sewage sludge and the content was emptied into the sand bed. Discharge were recorded at 20 minutes intervals until flow stopped. Equal quantities of ferric chloride salt, $20 \mathrm{~g}$ weight each, were also dissolved in $20 \mathrm{~cm}^{3}$ of distilled water and stored in five water bottles with their covers tightly closed so that the contents cannot absorb moisture from the atmosphere. The same experiment was repeated using coagulant that has lasted in water for 24 hours, 48hours, 72 hours, 96 hours and 120 hours respectively, corresponding to day 2 , day 3 , day 4 , day 5 and day 6. Discharge were also measured and recorded until stoppage of flow. Instantaneous inhibition coefficients which is the ratio of the difference between cumulative discharge for control experiment and cumulative discharge for day ' $n$ ', to cumulative discharge for control experiment, were determined using the expression;

$I_{i}=\frac{Q_{c}-Q_{n}}{Q_{c}}$

In (4), $I_{i}$ instantaneous inhibition coefficient, $Q_{c}$ is the cumulative discharge for control experiment and $Q_{n}$ is the cumulative discharge for any day ' $n$ ' where $n=2$ to 6 days.

Specific resistance to filtration $R$, were determined using the relationship developed by [23] thus;

$R=\left(\frac{\rho g h A^{2}}{\mu C}\right) b$

In (5), $A$ is the surface area of filtration $\left(\mathrm{m}^{2}\right), \mathrm{C}$ is the solid content $\left(\mathrm{kg} / \mathrm{m}^{3}\right)$, $\rho \mathrm{gh}$ is the hydrostatic pressure, $\left(\mathrm{N} / \mathrm{m}^{2}\right), \mathrm{R}$ is the specific resistance to filtration, $\mathrm{V}$ is the ${ }_{\mathrm{v}}$ olume of filtrate/discharge $\left(\mathrm{m}^{3}\right), \mu$ is the dynamic viscosity (N.s $/ \mathrm{m}^{2}$ ) and $\mathrm{b}$ is the slope. The slope $b$ is given by the expression

$b=\frac{n \sum v \cdot t / v-\sum v \sum t / v}{n \sum v^{2}-\left(\sum v\right)^{2}}$

The experimental set up is shown in Figure 1.

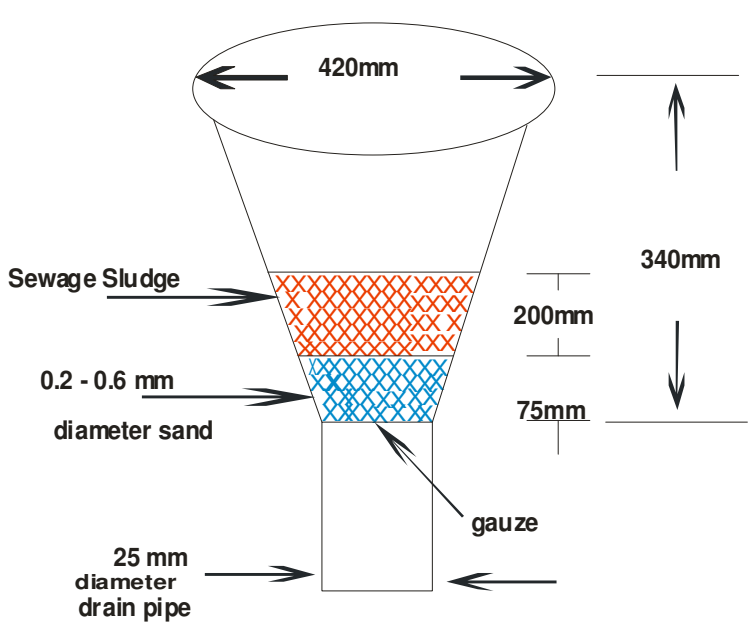

Figure 1: Sectional view of drying bed

\section{3, RESULTS AND DISCUSSIONS}

Table 1 represents the relationship between instantaneous discharge and time, while Table 2 shows the relationship between cumulative discharge and time. The results show that the duration of flow for day 1(i.e. control experiment) is further and faster because flow stopped at the $400^{\text {th }}$ minute. On the second day of the experiment, when the $\mathrm{FeCl}_{3}$ conditioner have lasted for 24 hours in water, flow stopped at $300^{\text {th }}$ minute. The same experiment was conducted for the remaining four days and results showed that flow stopped at the $200^{\text {th }}$ minute for day 3 and day 4 and at the $160^{\text {th }}$ minute for day 5 and day 6 , implying that the longer the coagulant stays in water, the lesser the efficacy. For the control experiment (i.e. day 1), maximum discharge of 201 $\mathrm{cm}^{3}$ was experienced at the $400^{\text {th }}$ minute. This implies that discharge from the control experiment was further and faster and differs from discharge for the day 2 by $123 \mathrm{~cm}^{3}$. For day 2, maximum discharge was $78 \mathrm{~cm}^{3}$ and occurred at the $300^{\text {th }}$ minute. For day 3 and day 4, maximum discharges were $41 \mathrm{~cm}^{3}$ and $40 \mathrm{~cm}^{3}$ with flow stopping at the $200^{\text {th }}$ minute respectively. Furthermore, day5 and day6 had maximum discharges of $39 \mathrm{~cm}^{3}$ each. It is evident that there was no much difference in discharges from day 
3 to day 6 because there was only a change of $2 \mathrm{~cm}^{3}$, it was $37 \mathrm{~cm}^{3}$ between day 2 and day 3, so that these results indicate that the efficacy of $\mathrm{FeCl}_{3}$ conditioner decreased so rapidly the longer it stays in solution. Efficacy reduction ratios which are the ratios of maximum discharge for control experiment to maximum discharge for any given day were 1:2.577; $1: 4.902 ; 1: 5.025 ; 1: 5.154 ; 1: 5.154$, for days 2 to 6 which implies that efficacy was retarded by a factor of 2.577 after 24 hours in solution, it was 4.902, 5.025, 5.154 and 5.154 when the conditioner has lasted in solution for 48hours, 72 hours, 96hours and 120 hours respectively.

Table 1: Relationship between instantaneous

\begin{tabular}{ccccccc}
\multicolumn{7}{c}{ discharge and time } \\
\hline \multirow{2}{*}{ Time } & \multicolumn{7}{c}{ Instantaneous discharge $\left(\mathrm{cm}^{3}\right)$} \\
\cline { 2 - 7 } & Day 1 & Day & Day & Day & Day & Day \\
& (Control) & 2 & 3 & 4 & 5 & 6 \\
\hline 20 & 25 & 12 & 8 & 7 & 7 & 6 \\
40 & 22 & 9 & 4 & 4 & 7 & 6 \\
60 & 19 & 7 & 4 & 4 & 5 & 6 \\
80 & 16 & 8 & 4 & 4 & 4 & 5 \\
100 & 15 & 6 & 4 & 4 & 4 & 4 \\
120 & 15 & 4 & 4 & 4 & 4 & 5 \\
140 & 11 & 4 & 4 & 4 & 4 & 4 \\
160 & 9 & 4 & 4 & 4 & 4 & 3 \\
180 & 10 & 4 & 4 & 4 & - & - \\
200 & 9 & 4 & 2 & 1 & - & - \\
220 & 8 & 4 & - & - & - & - \\
240 & 8 & 4 & - & - & - & - \\
260 & 8 & 4 & - & - & - & - \\
280 & 4 & 3 & - & - & - & - \\
300 & 4 & 1 & - & - & - & - \\
320 & 4 & - & - & - & - & - \\
340 & 4 & - & - & - & - & - \\
360 & 4 & - & - & - & - & - \\
380 & 4 & - & - & - & - & - \\
400 & 2 & - & - & - & - & - \\
\hline
\end{tabular}

In Table 4, the relationship between instantaneous inhibition coefficients and time were shown. These values represent the degree by which dewaterability is retarded when the conditioner is in solution. It shows that the least inhibition was noticed after 24 hours (i.e. day 2), followed by day3, day 4 , day 5 , and day 6 in ascending order of magnitude. The minimum inhibition of $52 \%$ (i.e. 0.52 ) was observed in the first $20^{\text {th }}$ minute in the second day of the experiment., while a maximum inhibition of $78 \%$ was encountered in the $60^{\text {th }}$ minute during the third day of the experiment. Other results fall within this range implying remarkable inhibition between $52 \%$ and $78 \%$.

Table 2: Relationship between cumulative discharge and time

\begin{tabular}{ccccccc}
\hline \multirow{2}{*}{$\begin{array}{c}\text { Time } \\
\text { (mins) }\end{array}$} & \multicolumn{6}{c}{ Instantaneous discharge $\left(\mathrm{cm}^{3}\right)$} \\
\cline { 2 - 7 } & Day1 & Day & Day & Day & Day & Day \\
\hline 20 & 25 & 12 & 8 & 7 & 7 & 6 \\
40 & 47 & 21 & 12 & 11 & 14 & 12 \\
60 & 66 & 28 & 16 & 15 & 19 & 18 \\
80 & 82 & 36 & 20 & 19 & 23 & 23 \\
100 & 97 & 42 & 24 & 23 & 27 & 27 \\
120 & 112 & 46 & 28 & 27 & 31 & 32 \\
140 & 123 & 50 & 32 & 31 & 35 & 36 \\
160 & 132 & 54 & 36 & 35 & 39 & 39 \\
180 & 142 & 58 & 39 & 39 & - & - \\
200 & 151 & 62 & 41 & 40 & - & - \\
220 & 159 & 66 & - & - & - & - \\
240 & 167 & 70 & - & - & - & - \\
260 & 175 & 74 & - & - & - & - \\
280 & 179 & 77 & - & - & - & - \\
300 & 183 & 78 & - & - & - & - \\
320 & 187 & - & - & - & - & - \\
340 & 191 & - & - & - & - & - \\
360 & 195 & - & - & - & - & - \\
380 & 199 & - & - & - & - & - \\
400 & 201 & - & - & - & - & - \\
\hline
\end{tabular}

Table 3: Difference between cumulative discharge for control experiment and cumulative discharge at various days and time

\begin{tabular}{ccccccc}
\hline & Control & \multicolumn{5}{c}{$Q_{c}-Q_{n}\left(\mathrm{~cm}^{3}\right)$} \\
Time & (i.e. Day 1) & \multicolumn{5}{c}{} \\
\cline { 3 - 7 } & $Q_{c}\left(\mathrm{~cm}^{3}\right)$ & Day & Day & Day & Day & Day \\
\hline 20 & 25 & 13 & 17 & 4 & 5 & 6 \\
40 & 47 & 26 & 35 & 36 & 33 & 35 \\
60 & 66 & 38 & 50 & 51 & 47 & 48 \\
80 & 82 & 46 & 62 & 63 & 59 & 59 \\
100 & 97 & 55 & 73 & 74 & 70 & 70 \\
120 & 112 & 66 & 84 & 85 & 81 & 80 \\
140 & 123 & 73 & 91 & 92 & 88 & 87 \\
160 & 132 & 78 & 96 & 97 & 93 & 93 \\
180 & 142 & 84 & 103 & 103 & - & - \\
200 & 151 & 89 & 110 & 111 & - & - \\
220 & 159 & 93 & - & - & - & - \\
240 & 167 & 97 & - & - & - & - \\
260 & 175 & 101 & - & - & - & - \\
280 & 179 & 102 & - & - & - & - \\
300 & 183 & 105 & - & - & - & - \\
320 & 187 & - & - & - & - & - \\
340 & 191 & - & - & - & - & - \\
360 & 195 & - & - & - & - & - \\
380 & 199 & - & - & - & - & - \\
400 & 201 & - & - & - & - & - \\
\hline
\end{tabular}


Table 4: Relationship between instantaneous inhibition coefficients and time

\begin{tabular}{cccccc}
\hline \multirow{2}{*}{ Time (mins) } & \multicolumn{5}{c}{ Instantaneous inhibition coefficients } \\
\cline { 2 - 6 } & Day 2 & Day 3 & Day 4 & Day 5 & Day 6 \\
\hline 20 & 0.52 & 0.68 & 0.72 & 0.72 & 0.76 \\
40 & 0.55 & 0.74 & 0.76 & 0.70 & 0.74 \\
60 & 0.58 & 0.78 & 0.77 & 0.71 & 0.73 \\
80 & 0.56 & 0.76 & 0.77 & 0.72 & 0.72 \\
100 & 0.57 & 0.75 & 0.76 & 0.72 & 0.72 \\
120 & 0.59 & 0.75 & 0.76 & 0.72 & 0.71 \\
140 & 0.59 & 0.73 & 0.75 & 0.72 & 0.71 \\
160 & 0.59 & 0.73 & 0.74 & 0.70 & 0.70 \\
180 & 0.59 & 0.73 & 0.73 & - & - \\
200 & 0.59 & 0.73 & 0.74 & - & - \\
220 & 0.58 & - & - & - & - \\
240 & 0.58 & - & - & - & - \\
260 & 0.58 & - & - & - & - \\
280 & 0.57 & - & - & - & - \\
300 & 0.56 & - & - & - & - \\
\hline
\end{tabular}

\subsection{Specific Resistance To Filtration}

Specific resistance to filtration were computed for the six days as shown in Tables 5 to 10 . Specific resistance to filtration may be defined as the resistance of sludge, having a unit weight of dry solids per unit area at a given pressure, to a unit rate of flow of liquid having unit viscosity [24].

Determination of solid content of sludge:

Moisture content of sludge $=82.21 \%$

Weight of solids + water $=4000 \mathrm{~g}$

Weight of water, $\frac{82.21}{100} \times 4000=3288.40 \mathrm{~g}$

Volume of sludge $=0.00568 \mathrm{~m}^{3}$

Weight of solids $4000-3288.40=711.60 \mathrm{~g}$

Solid content (C), mass/vol. $=0.7116 / 0.00568=125.28 \mathrm{~kg} / \mathrm{m}^{3}$

Table 5: Specific resistance to filtration for day 1 (i.e. control)

\begin{tabular}{ccccc}
\hline $\begin{array}{c}\text { Time } t \\
(\text { mins })\end{array}$ & $v \times 10^{-5}\left(m^{3}\right)$ & $t / v \times 10^{8}$ & $v^{2} \times 10^{-10}$ & $v * t / v$ \\
\hline 20 & 2.5 & 0.0080 & 6.25 & 20 \\
40 & 2.2 & 0.0182 & 4.84 & 40 \\
60 & 1.9 & 0.0316 & 3.61 & 60 \\
80 & 1.6 & 0.0500 & 2.56 & 80 \\
100 & 1.5 & 0.0670 & 2.25 & 100 \\
120 & 1.5 & 0.0800 & 2.25 & 120 \\
140 & 1.1 & 0.1300 & 1.21 & 140 \\
160 & 0.9 & 0.1778 & 0.81 & 160 \\
180 & 1.0 & 0.1800 & 1.00 & 180 \\
200 & 0.9 & 0.2222 & 0.81 & 200 \\
220 & 0.8 & 0.2750 & 0.64 & 220 \\
240 & 0.8 & 0.3000 & 0.64 & 240 \\
260 & 0.8 & 0.3250 & 0.64 & 260 \\
280 & 0.4 & 0.7000 & 0.16 & 280 \\
300 & 0.4 & 0.7500 & 0.16 & 300 \\
320 & 0.4 & 0.8000 & 0.16 & 320 \\
340 & 0.4 & 0.8500 & 0.16 & 340 \\
360 & 0.4 & 0.9000 & 0.16 & 360 \\
380 & 0.4 & 0.9500 & 0.16 & 380
\end{tabular}

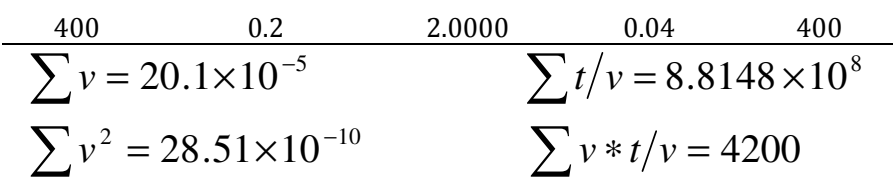

Initial sludge thickness $=200 \mathrm{~mm}, \Delta h=69.45 \mathrm{~mm}$, $h=200-69.45=130.55 \mathrm{~mm}$, Density of water $\rho_{w}$ $=996.23 \mathrm{~kg} / \mathrm{m}^{3}$, Surface area $(A)=0.0932 \mathrm{~m}^{2}$, hydrostatic pressure $\rho_{w} g h=1275.87 \mathrm{~N} / \mathrm{m}^{2}$, dynamic viscosity of water $\mu_{w}=0.8917 N . \mathrm{s} / \mathrm{m}^{2}$, solid content, $(c)$ mass $/$ vol. $=125.28 \mathrm{~kg} / \mathrm{m}^{3}$, $b=4.407 \times 10^{7}, R=4.372 \times 10^{6} \mathrm{~m} / \mathrm{kg}$

Table 6: Specific resistance to filtration for day 2 Time $t \quad v \times 10^{-5}\left(m^{3}, t / v \times 10^{8} \quad v^{2} \times 10^{-10} \quad v * t / v\right.$ (mins)

\begin{tabular}{ccccc}
\hline 20 & 1.2 & 0.0167 & 1.44 & 20 \\
40 & 0.9 & 0.0444 & 0.81 & 40 \\
60 & 0.7 & 0.0857 & 0.49 & 60 \\
80 & 0.8 & 0.1000 & 0.64 & 80 \\
100 & 0.6 & 0.1667 & 0.36 & 100 \\
120 & 0.4 & 0.3000 & 0.16 & 120 \\
140 & 0.4 & 0.3500 & 0.16 & 140 \\
160 & 0.4 & 0.4000 & 0.16 & 160 \\
180 & 0.4 & 0.4500 & 0.16 & 180 \\
200 & 0.4 & 0.5000 & 0.16 & 200 \\
220 & 0.4 & 0.5500 & 0.16 & 220 \\
240 & 0.4 & 0.6000 & 0.16 & 240 \\
260 & 0.4 & 0.6500 & 0.16 & 260 \\
280 & 0.3 & 0.9333 & 0.09 & 280 \\
300 & 0.1 & 3.0000 & 0.01 & 300 \\
\hline$\sum v=7.8 \times 10^{-5}$ & \multicolumn{3}{c}{$\sum t / v=8.1468 \times 10^{8}$} \\
$\sum v^{2}=5.12 \times 10^{-10}$ & \multicolumn{3}{c}{$\sum v * t / v=2400$}
\end{tabular}

Initial sludge thickness $=200 \mathrm{~mm}, \Delta h=62.55 \mathrm{~mm}$, $h=200-62.55=137.45 \mathrm{~mm}$, Density of water $\rho_{w}$ $=996.23 \mathrm{~kg} / \mathrm{m}^{3}$, Surface area $(A)=0.0932 \mathrm{~m}^{2}$, hydrostatic pressure $\rho_{w} g h=1343.30 \mathrm{~N} / \mathrm{m}^{2}$, dynamic viscosity of water $\mu_{w}=0.8917 \mathrm{~N} . \mathrm{s} / \mathrm{m}^{2}$, solid content, $(c)$ mass $/$ vol. $=125.28 \mathrm{~kg} / \mathrm{m}^{3}$, $b=1.842 \times 10^{13}, R=1.924 \times 10^{12} \mathrm{~m} / \mathrm{kg}$.

Table 7: Specific resistance to filtration for day 3

\begin{tabular}{ccccc}
$\begin{array}{c}\text { Time } t \\
\text { (mins) }\end{array}$ & $v \times 10^{-5}\left(m^{3}, t / v \times 10^{8}\right.$ & $v^{2} \times 10^{-10}$ & $v * t / v$ \\
\hline 20 & 0.8 & 0.025 & 0.64 & 20 \\
40 & 0.4 & 0.100 & 0.16 & 40 \\
60 & 0.4 & 0.150 & 0.16 & 60 \\
80 & 0.4 & 0.200 & 0.16 & 80 \\
100 & 0.4 & 0.250 & 0.16 & 100 \\
120 & 0.4 & 0.300 & 0.16 & 120 \\
140 & 0.4 & 0.350 & 0.16 & 140 \\
160 & 0.4 & 0.400 & 0.16 & 160 \\
180 & 0.3 & 0.600 & 0.09 & 180
\end{tabular}

Time $t \quad v \times 10^{-5}\left(m^{3}, t / v \times 10^{8} \quad v^{2} \times 10^{-10} \quad v * t / v\right.$ (mins) 




Initial sludge thickness $=200 \mathrm{~mm}, \Delta h=55.65 \mathrm{~mm}$, $h=200-55.65=138.35 \mathrm{~mm}$ Density of water $\rho_{w}$ $=996.23 \mathrm{~kg} / \mathrm{m}^{3}$, Surface $\operatorname{area}(A)=0.0932 \mathrm{~m}^{2}$, hydrostatic pressure $\rho_{w} g h=1410.74 \mathrm{~N} / \mathrm{m}^{2}$, dynamic viscosity of water $\mu_{w}=0.8917 \mathrm{~N} . \mathrm{s} / \mathrm{m}^{2}$, solid content, $(c)$ mass $/$ vol. $=125.28 \mathrm{~kg} / \mathrm{m}^{3}$, $b=1.358 \times 10^{13}, R=1.49 \times 10^{12} \mathrm{~m} / \mathrm{kg}$.

Table 8: Specific resistance to filtration for day 4

\begin{tabular}{ccccc}
\hline $\begin{array}{c}\text { Time } t \\
(\text { mins })\end{array}$ & $v \times 10^{-5}\left(\mathrm{~m}^{3}\right)$ & $t / v \times 10^{8}$ & $v^{2} \times 10^{-10}$ & $v * t / v$ \\
\hline 20 & 0.7 & 0.0296 & 0.4900 & 20 \\
40 & 0.4 & 0.1000 & 0.1600 & 40 \\
60 & 0.4 & 0.1500 & 0.1600 & 60 \\
80 & 0.4 & 0.2000 & 0.1600 & 80 \\
100 & 0.4 & 0.2500 & 0.1600 & 100 \\
120 & 0.4 & 0.3000 & 0.1600 & 120 \\
140 & 0.4 & 0.3500 & 0.1600 & 140 \\
160 & 0.4 & 0.4000 & 0.1600 & 160 \\
180 & 0.4 & 0.4500 & 0.1600 & 180 \\
200 & 0.1 & 2.0000 & 0.0100 & 200 \\
\hline$\sum v=4.0 \times 10^{-5}$ & \multicolumn{3}{c}{$\sum t / v=4.229 \times 10^{8}$} \\
$\sum v^{2}=1.79 \times 10^{-10}$ & \multicolumn{3}{c}{$\sum v t / v=1100$}
\end{tabular}

Initial sludge thickness $=200 \mathrm{~mm}, \Delta h=55.05 \mathrm{~mm}$, $h=200-55.05=144.95 \mathrm{~mm}$,Density of water $\rho_{w}$ $=996.23 \mathrm{~kg} / \mathrm{m}^{3}$, Surface area $(A)=0.0932 \mathrm{~m}^{2}$, hydrostatic pressure $\rho_{w} g h=1416.60 \mathrm{~N} / \mathrm{m}^{2}$, dynamic viscosity of water $\mu_{w}=0.8917 \mathrm{~N} . \mathrm{s} / \mathrm{m}^{2}$, solid content, $(c)$ mass $/$ vol. $=125.28 \mathrm{~kg} / \mathrm{m}^{3}$, $b=3.228 \times 10^{13}, R=3.556 \times 10^{12} \mathrm{~m} / \mathrm{kg}$.

Table 9: Specific resistance to filtration for day 5

\begin{tabular}{ccccc}
\hline $\begin{array}{c}\text { Time } \\
t \\
(\mathrm{mins})\end{array}$ & $v \times 10^{-5}\left(\mathrm{~m}^{3}\right)$ & $t / v \times 10^{8}$ & $v^{2} \times 10^{-10}$ & $v * t / v$ \\
\hline 20 & 0.7 & 0.0286 & 0.49 & 20 \\
40 & 0.7 & 0.0571 & 0.49 & 40 \\
60 & 0.5 & 0.1200 & 0.25 & 60 \\
80 & 0.4 & 0.2000 & 0.16 & 80 \\
100 & 0.4 & 0.2500 & 0.16 & 100 \\
120 & 0.4 & 0.3000 & 0.16 & 120 \\
140 & 0.4 & 0.3500 & 0.16 & 140 \\
160 & 0.4 & 0.4000 & 0.16 & 160 \\
\hline$\sum v=3.90 \times 10^{-5}$ & \multicolumn{3}{c}{$\sum t / v=1.706 \times 10^{8}$} \\
$\sum v^{2}=2.03 \times 10^{-10}$ & \multicolumn{3}{c}{$\sum v * t / v=720$}
\end{tabular}

Initial sludge thickness $=200 \mathrm{~mm}, \Delta h=35.00 \mathrm{~mm}$, $h=200-35.00=165.00 \mathrm{~mm}$, Density of water $\rho_{w}$ $=996.23 \mathrm{~kg} / \mathrm{m}^{3}$, surface area $(A)=0.0932 \mathrm{~m}^{2}$, hydrostatic pressure $\rho_{w} g h=1612.55 \mathrm{~N} / \mathrm{m}^{2}$, dynamic viscosity of water $\mu_{w}=0.8917 \mathrm{~N} . \mathrm{s} / \mathrm{m}^{2}$, solid content, $(c)$ mass $/$ vol. $=125.28 \mathrm{~kg} / \mathrm{m}^{3}$, $b=3.2280 \times 10^{13}, R=2.310 \times 10^{12} \mathrm{~m} / \mathrm{kg}$.

Table 10: Specific resistance to filtration for day 6

\begin{tabular}{ccccc}
\hline $\begin{array}{c}\text { Time } t \\
(\mathrm{mins})\end{array}$ & $v \times 10^{-5}\left(\mathrm{~m}^{3}\right)$ & $t / v \times 10^{8}$ & $v^{2} \times 10^{-10}$ & $v * t / v$ \\
\hline 20 & 0.6 & 0.0333 & 0.36 & 20 \\
40 & 0.6 & 0.0667 & 0.36 & 40 \\
60 & 0.6 & 0.1000 & 0.36 & 60 \\
80 & 0.5 & 0.1600 & 0.25 & 80 \\
100 & 0.4 & 0.2500 & 0.16 & 100 \\
120 & 0.5 & 0.2400 & 0.25 & 120 \\
140 & 0.4 & 0.3500 & 0.16 & 140 \\
160 & 0.3 & 0.5333 & 0.09 & 160 \\
\hline$\sum v=3.9 \times 10^{-5}$ & \multicolumn{3}{c}{$\sum t / v=1.733 \times 10^{8}$} \\
$\sum v^{2}=1.99 \times 10^{-10}$ & \multicolumn{3}{c}{$\sum v * t / v=720$}
\end{tabular}

Initial sludge thickness $=200 \mathrm{~mm}, \Delta h=35.00 \mathrm{~mm}$, $h=200-35.00=165.00 \mathrm{~mm}$, Density of water $\rho_{w}$ $=996.23 \mathrm{~kg} / \mathrm{m}^{3}$, surface area $(A)=0.0932 \mathrm{~m}^{2}$, hydrostatic pressure $\rho_{w} g h=1612.55 \mathrm{~N} / \mathrm{m}^{2}$, dynamic viscosity of water $\mu_{w}=0.8917 \mathrm{~N} . \mathrm{s} / \mathrm{m}^{2}$, solid content, $(c)$ mass $/ \mathrm{vol} .=125.28 \mathrm{~kg} / \mathrm{m}^{3}$, $b=1.408 \times 10^{13}, R=1.765 \times 10^{12} \mathrm{~m} / \mathrm{kg}$.

The results for the parameter, specific resistance to filtration $R$, show that these values increased tremendously when ferric chloride salt was dissolved and stored in solution. The values are $4.372 \times 10^{6} \mathrm{~m} / \mathrm{kg}$ for day $1,1.924 \times 10^{12} \mathrm{~m} / \mathrm{kg}$, $1.490 \times 10^{12} \mathrm{~m} / \mathrm{kg}, \quad 3.556 \times 10^{12} \mathrm{~m} / \mathrm{kg}$ ， $2.310 \times 10^{12} \mathrm{~m} / \mathrm{kg}$ and $1.765 \times 10^{12} \mathrm{~m} / \mathrm{kg}$, for day 2 , day 3 , day 4 , day 5 and day 6 respectively. There was no consistent increase in these values, but seem to be fluctuating. This behaviour is a limitation in the work of [23], and because of that their model is not so good in the prediction of specific resistance to filtration.

\section{CONCLUSION}

The purpose of this study was to know if Ferric Chloride can be preserved in solution and be used at a later date without losing its efficacy. Results indicate high level inhibition in the neighborhood of between 
$52 \%$ to $78 \%$. These results show drastic reduction in dewatering efficacy of this conditioner the longer it stays in solution. Efficacy retardation factors increased with age of the solution. Specific resistance to filtration increased so much but inconsistently with time. Therefore it is not advisable to preserve this substance in solution because it loses its dewatering capacity over time. It is recommended that once opened, it should be used within a period of hour and the remnant should be disposed. Manufacturers are advised to package this substance in cans containing about 50g, 100g, 200g of Ferric Chloride in order to reduce wastes whenever small quantities of this substance is needed in conducting experiments.

\section{REFERENCES}

[1] Metcalf, L., Eddy, H. P. (2004). Wastewater engineering: Treatment and reuse, $4^{\text {th }}$ Ed. McGrawHill Book Co. New York, N.Y. 10020. Pp. 1558-1565, 1570-1578

[2] Agunwamba, J. C. (2001). Waste engineering and management tools, Immaculate Publication Ltd. P.186.

[3] Garg, S.K. (2008). Sewage disposal and air pollution engineering. Khanna Publishers, 2-B, Nath Market, Nai Sarak, Delhi- 110006, pp. 401-404.

[4] Octavio, P. S. (2007). Impact of sludge pre-digestion: Disintegration on dewatering and polymer dose. M.Sc Thesis, Centre for Water Science, Cranfield University, pp.1-2.

[5] Texier, P. (2008) Effect of acidification on sludge dewatering properties. M.Sc Thesis, Water and Environmental Engineering, Department of Chemical Engineering, LTH, Lund University, Sweden. L. Article, p.78.

[6] Carman, P. C. (1934). A study of the mechanism of filtration, part II. Journal of the Society of Chemical Industry Transactions-communication; 53(6): 159T$165 \mathrm{~T}$.

[7] Carman, P.C. (1938). Fundamental principles of industrial filtration. Transactions-Institution of Chemical Engineers; 16: 168-188.

[8] Ruth, B.F. (1935). Studies in filtration- Derivation of general filtration equation. Industrial and Engineering Chemistry, 25(1): 76-82.

[9] Anazodo, U.G.N. (1975). Dimensional equation for sludge filtration. Effluent and Water treatment Journal, pp. 422-423.

[10] Qasim, S. R., Motley, E. M., Zhu, G., (2000). Water works engineering: Planning, design, and operation, Prentice Hall PTR, New Jersey.

[11] Cornwell, D. A., (1996), Water treatment plant residuals management, In: R.D. Letterman (Ed.)
Water Quality and Treatment (A Handbook of Community Water Supplies), fifth edition, McGrawHill, New York, pp. 16.1 - 16.51

[12] Bertsch, P. M., Parker, D. R., (1996). Aqueous polynuclear aluminium species, In: G. Sposito (Ed.). The environmental chemistry of aluminium, 1, second edition, Lewis Publishers/CRC Press, Boca Raton. pp. 177 - 168.

[13] Cornell, R. M., Schwertmann, U., (2003). The iron oxides: Structure, Properties, Reactions, Occurrences and Uses. Wiley-VCH, Weinheim, Germany.

[14] Cornell, R. M., Schwertmann, U., (1996). The iron oxides: Structure, Properties, Reactions, Occurrences and Uses. Second edition, Wiley VCH Weinheim, Germany.

[15] Russell, J. S., Peck, B. E., (1998). Process residuals, In: A.W.W.A., A.S.C.E., (Eds.) Water Treatment Plant Design, third edition, McGraw-Hill, New York, pp. $485-530$.

[16] Parsons, S. A., Jefferson, B., (2006). Introduction to potable water treatment processes, Blackwell, Oxford, UK.

[17] Dillon, G., (1997). Application guide to waterworks sludge treatment and disposal. WRc, Swindon, England.

[18] Ogilvie, D., (2005). New Zealand Interim Guidelines: Management of water treatment sludge. http://www.smf.govt.nz/projects/summary.php?ser ies $=4000$.

[19] Papavasilopoulos, E.N., Bache, D.H., (2001)., Sludge management entering the $3^{\text {rd }}$ millennium industrial, combined, water and wastewater residues, International Water Association, Taipei, Taiwan. pp.476 - 483.

[20] Verrelli, D.I., Dixon, D.R., Scales, P.J., (2009). Colloids and surfaces A: Physicochemical and engineering aspects. Elsevier B.V. Particulate Fluids Processing Centre, Department of Chemical and Biomolecular Engineering, the University of Melbourne, Victoria 3010, Australia.

[21] Obianyo, J. I., Agunwamba, J. C., (2014). Effect of conditioner on dewaterability of sewage sludge. Nigerian Journal of Technology, Vol. 33, No. 3.

[22] British Standard 1377 (1975). Methods of test for soils for civil engineering purposes, British Standards Institution, British Standards House, 2 Park Street London.

[23] Ademiluyi, J.O., Arimieari, L.W. 2012. Evaluating the specific resistance of conditioned sludge on natural drying bed. International Journal of Current Research, Vol. 4. Issue, 02, pp.157-161

[24] Berktay, A. 1998. Properties of sludge produced from the pressurized wastewater treatment process. Tr. J. of Engineering and Environmental Science. 22: $377-385$. 